\title{
Anthropological Portrait of the Man by the Poet Nikolai Gumilev
}

\author{
Safiulina Rano* \\ Department of Russian language and literatureю, Moscow Sinergy University, Russia
}

Submission: February 28, 2019; Published: March 15, 2019

*Corresponding author: Safiulina Rano, Department of Russian language and literatureю. Moscow Sinergy University, Moscow, Russian Federation, Russia

\section{Mini Review}

The poetry of Nikolai Gumilev (1886-1921) is an artistic understanding of the crisis era of the early twentieth century, when humanity learned to live in the new realities of God's Death, Charles Darwin's theory, the omnipotence of science, the destruction of the classical understanding of man as the center of the universe, the measure of things, the focus the universe. The Russian poet was born in Kronstadt near St. Petersburg, studied at St. Petersburg University and at the Sorbonne, and met with English imagists. His poetry was influenced by the philosophical ideas of Henri Bergson, Friedrich Nietzsche and Vladimir Solovyov. Gumilev's poetic creativity covers only 16 years (1905 - 1921). Over the years, he published a collection of poems "The Way of the Conquistadors" (1905), "Romantic Flowers" (1908), "Alien Sky" (1912), "Quiver" (1916), "Bonfire”, “ Tent ",'Pillar of Fire"(1918). He founded the literary direction Acmeism, made three trips to Africa, where he collected Abyssinian folklore. He volunteered in World War I and was awarded two George crosses for personal courage. N. S. Gumilev was arrested on charges of involvement in a counter-revolutionary conspiracy and was shot on August 25, 1921. Gumilev was married to poetess Anna Akhmatova.

In the 1910s, Gumilev creates innovative poetry, which reflects the global trends of art. The main object of the poet's creativity is Man. At the center of the poet's work is the anthropological proto-model of man, evrimen. The anthropological architectonics of Gumilev's lyric collections is caused by the task of representing the essential characteristics of man - a kind of answer to the problem of "the search for man", acute for a given era. The complexity and ambiguity of the psychology of the human person are depicted by the poet, based on the new scientific discoveries of the early twentieth century: anthropology, phenomenology, psychoanalysis, sociology. The man of Gumilev is probably the last artistic portrait of the beginning of the twentieth century, where a person is depicted as an integral and harmonious personality, as an intelligent, strong, resilient, able to withstand the trials of life: the tragic fate, the betrayal of the Father; death share. Knowing how short his age is, he fights, works, loves, hates, creates great works of art. His gaze is directed not only at the near world around him, but he embraces the cosmos with his consciousness. Gumilev's man is Homo faber, he is an actor of his own fate, directed to an unknown future, and he is the embodiment of the archetype of the Hero.

In Gumilev's poem "Body and Soul”, the amazed God asks the question: "Who are you, man?". This question indicates that the Creator overlooked the formation of man; he did not expect such impressive results from those weak, fearful, dependent beings whom he sent to the harsh reality, actually to death, as a punishment for knowledge. The answer of the person shows both "mercy" and "audacity"; in him, the wisdom of a man who paid dearly for this wisdom, and gratitude to God for the wonderful world - the cosmos in which he lives, and self-doubt (Darwin's allusion; man is only a link in the evolutionary chain, a biological being, akin to a dog that howls if the month is light "), and pride in himself, who survived and got on his feet, and raised a bold gaze to heaven.

The representation of N. Gumilev of the pendulum from the work of A. Bergson "Creative Evolution" allowed the poet to give a deep insight into the tragic transience of human existence in his works [1]. The pendulum in the clock turns into Gumilev's poetry into a meta-image that has a huge semantic meaning. Deviations of the pendulum from the norm become for a person an important factor of progress, evolution, a stimulus to selfimprovement, development. The menacing and implacable steps of the pendulum make a person N. Gumilev rush to live, create and show the best human qualities.

\section{References}

1. Bergson H (1911) Creative Evolution. Authorized Translation by Arthur Mitchell, Henry Holt and Company, New York, USA. 
(C) (1) This work is licensed under Creative

BY DOI: 10.19080/GJAA.2019.08.555738
Your next submission with Juniper Publishers will reach you the below assets

- Quality Editorial service

- Swift Peer Review

- Reprints availability

- E-prints Service

- Manuscript Podcast for convenient understanding

- Global attainment for your research

- Manuscript accessibility in different formats

( Pdf, E-pub, Full Text, Audio)

- Unceasing customer service

Track the below URL for one-step submission https://juniperpublishers.com/online-submission.php 